\title{
BREXIT AND EUROPEAN FINANCIAL SYSTEM
}

\section{TINATIN GUGESHASHVILI}

Academic Doctor of Economics,

Associated Professor of Akaki Tsereteli State University, Georgia https://doi.org/10.35945/gb.2017.04.001

\section{KEYWORDS: BREXIT, FINANCIAL CENTRE, WHOLESALE MARKETS}

\section{BREXIT AND EUROPEAN FINANCIAL SYSTEM}

London is Europe's financial centre, providing corporate and investment banking services to the European Union's 28 member countries and beyond. When the United Kingdom leaves the EU and its single market by the spring of 2019, UK-based financial firms wil lose their passport to do direct business with EU27 clients. Brexit thus leads to a partial migration of financial firms from London to the EU27 (EU minus the UK) so that they could continue to serve their customers there.

We provide a comparison between London and four major cities that together will host most of the new EU27 wholesale market: Frankfurt, Paris, Dublin and Amsterdam. We also give a detailed picture of the wholesale markets (foreign exchange, securities and derivatives trading), the largest players in these markets (the major banks) and the underlying clearing infrastructure.

London is an international financial centre, serving European and global clients. A hard Brexit would lead to a partial migration of financial firms from London to the EU27 (EU minus UK) to ensure they can continue to serve their EU27 clients.

Four major cities will host most of the new EU27 wholesale markets: Frankfurt, Paris, Dublin and Amsterdam. These cities have far fewer people employed in finance than London. Moreover, they host the European headquarters of fewer large companies. The partial migration of financial firms will thus have a major impact on these cities and their infrastructures.

As some 35 percent of wholesale market activities might migrate from London to other major cities in the EU, it is instructive to compare the current 'capacity' of cities in terms of the size of their current financial market activities and their ability to host incoming activities from London. In section 5 , we estimate that some 30,000 people might relocate from London to the EU27: 10,000 related to core wholesale banking and 18,000 to 20,000 related to professional services.

There are differences in the size of the financial sectors in London and other European financial centres - Frankfurt, Paris, Dublin and Amsterdam. Where data for the city is not available, Table 1 gives country data. These numbers help us to understand capacity constraints when considering a partial relocation of the financial sector.

All five cities have strong financial sectors. The cities' shares of gross value added from their country's financial sector ranges from 23 to 25 percent in Paris and Amsterdam to 52 percent in London and to 80 percent in Dublin. London and Dublin in particular offer international financial services. While all five cities host a large number of domestically registered monetary financial institutions (MFIs), London dwarves the other cities in terms of foreign-registered MFIs. It shows London's pre-eminent position as the international financial hub in the EU. This finding is supported by the fact that London also hosts the largest number of headquarters of top companies.

In terms of characteristics of the financial sector, London outweighs the other cities by an even greater margin. The UK financial sector trade balance, to which London contributes the biggest share, is greater than that of France, Germany, Ireland and Amsterdam by a factor of more than 10. Tax revenues from the UK financial sector are more than 100 times greater than, for example, in Germany.

In terms of banking, the UK hosts more assets, capital and reserves than any other EU country. However, the proportion of finance staff to total population is lower in London than in Frankfurt, Dublin or Amsterdam. Finally, London has a leading role in forex and interest rate over-the-counter (OTC) derivatives turnover.

The large investment banks from the US and the large universal banks from Europe are essential players in the wholesale markets. These banks bring together the suppliers of capital (investors) and those with a need for capital (corporates, governments and households). In this way, these banks are the gatekeepers of the EU Capital Markets Union, which aims to improve access to funding, allocation of capital and better saving rates for savers. Investment bank league tables rank investment banks by market share and typically cover four major segments: mergers and acquisitions, equity, bonds and loans (ie syndicated loans). Table 2 on the next page show the top 20 banks, representing about 80 percent of the European investment banking market (Goodhart and Schoenmaker, 2016).

Detailed data on the investment banks show that an overwhelming share of their turnover and employment is located in the UK, highlighting the UK's role as a gateway to the continental European financial markets for third-country large financial firms. About 90 percent of the total EU turnover of the largest US and Swiss investment banks, and about an equal share of their EU staff, is located in the UK (Table 3). In the EU27, there is no single location where the largest third-country investment banks concentrate their activities. In general their activities are scattered. Nevertheless, we see some concentration in Frankfurt, Paris, Dublin and Amsterdam. Luxembourg is important for asset management, but that is outside the scope of this paper.

The activities that third-country investment banks already carry out in the EU27 are a good indicator of the location of their clients in the EU27. Assuming that the third-country investment banks will relocate mainly to where their clients are located, they will be likely to expand their ex- 
isting activities in the EU27. Ireland and Germany have large shares of the turnover and employment of Bank of America Merrill Lynch. Some of the largest operations of Citygroup are in France, Germany and Spain. For Goldman Sachs, the Netherlands is significant in terms of turnover and Germany in terms of employment. The highest shares of JP Morgan's EU27 turnover are in Luxembourg and Germany, and the highest shares of employment are in Ireland, Luxembourg and Germany. The largest shares of Morgan Stanley's EU27 operations are in France and to a lesser extent Italy. Lastly, Credit Suisse operates mainly through two UK-based entities, Credit Suisse International and Credit Suisse Securities Ltd. The largest Credit Suisse EU27 branches are in France and Germany, which represent larger shares in terms of turnover than in terms of staff.

London is a global player and a European hub for trading in terms of the size and diversity of its markets. It has an unparalleled position in terms of over-the-counter (OTC) foreign exchange and interest rate derivatives trading, particularly in the euro market and to a great extent the US dollar market. In terms of foreign exchange trading, the electronic nature of the transactions and the UK's dominant position in the market lead us to believe that the UK's position in forex trading will largely remain unchanged after Brexit. Moreover, forex trading in London is settled through Continuous Linked Settlement (CLS), a global multi-currency settlement system, and it is not depended on London's access to Target2, the ECB's settlement system, if the access to Target2 is disrupted after Brexit (Schoenmaker, 2017).

Almost half (43 percent) of the daily foreign exchange spot transactions in euros takes place in the UK (Figure 1) followed by US (19 percent), France ( 5 percent), Singapore (4 percent) and Germany (3 percent). Moreover, the UK is one of the biggest trading centres for major emerging countries' currencies and it is the most important destination for renminbi trading outside of Hong Kong.

The UK has established its position as the biggest FinTech and financial innovation centre in Europe, followed by Germany, with other EU countries far behind (TheCityUK, 2016b). Globally, the UK leads in terms of market size and is the second after the US in terms of investment and employment. The British FinTech industry employs 61,000 people, just below 6 percent of the total financial services workforce.

A growing export sector, especially for emerging markets and Association of Southeast Asian Nations (ASEAN) countries, FinTech has been a central part of the UK's global competitiveness strategy. Since the Brexit vote, however, venture capital investment has declined in the UK, while continuing to grow in Germany (KPMG, 2016). Decline in investment in the UK is partly due to political uncertainty delaying investment decisions in talent and human capital.

\section{REFERENCES:}

1. Barker, A. and J. Brunsden (2016) 'EU prepares rule changes to target City's euro clearing', Financial Times, December

2. Batsaikhan, U. (2016) 'Brexit and the UK's Euro-denominated market: the role of clearing houses', Bruegel Blog, 7 June

3. ECB (2016) Report on financial structures, European Central Bank

4. Europe Economics (2011) 'The Value of Europe's International Financial Centres to the EU Economy', London

5. Goodhart, C. and D. Schoenmaker (2016) 'The Global Investment Banks are now all Becoming American: Does that Matter for Europeans?', Journal of Financial Regulation, 2: 163-181

6. KPMG (2016) 'The Pulse of Fintech, Q3 2016 - Global Analysis of Fintech Venture Funding'

7. Sapir, A., D. Schoenmaker and N. Véron (2017) 'Making the Best of Brexit for the EU27 Financial System', Policy Brief 2017/01, Bruegel.

8. Scarpetta, V. and S. Booth (2016) How UK financial services can continue thriving after Brexit, Open Europe. 


\section{BREXIT AND EUROPEAN FINANCIAL SYSTEM}

TINATIN GUGESHASHVILI

https://doi.org/10.35945/gb.2017.04.001

Academic Doctor of Economics,

Associated Professor of Akaki Tsereteli State University, Georgia

KEYWORDS: BREXIT, FINANCIAL CENTRE, WHOLESALE MARKETS

\section{SUMMARY}

London is Europe's financial centre, providing corporate and investment banking services to the European Union's 28 member countries and beyond. When the United Kingdom leaves the EU and its single market by the spring of 2019, UK-based financial firms will lose their passport to do direct business with EU27 clients. Brexit thus leads to a partial migration of financial firms from London to the EU27 (EU minus the UK) so that they could continue to serve their customers there.

We provide a comparison between London and four major cities that together will host most of the new EU27 wholesale market: Frankfurt, Paris, Dublin and Amsterdam. We also give a detailed picture of the wholesale markets (foreign exchange, securities and derivatives trading), the largest players in these markets (the major banks) and the underlying clearing infrastructure.
London is an international financial centre, serving European and global clients. A hard Brexit would lead to a partial migration of financial firms from London to the EU27 (EU minus UK) to ensure they can continue to serve their EU27 clients.

Four major cities will host most of the new EU27 wholesale markets: Frankfurt, Paris, Dublin and Amsterdam. These cities have far fewer people employed in finance than London. Moreover, they host the European headquarters of fewer large companies. The partial migration of financial firms will thus have a major impact on these cities and their infrastructures.

Banks are the key players in wholesale markets. United States and Swiss investment banks, together with one large German and three large French banks, will make up the core of the new EU27 wholesale markets. Some Dutch, Italian and Spanish banks are in the second tier. 